\title{
THE CONFESSIO OF AN ACADEMIC AHAB: OR, HOW I SANK MY OWN DISCIPLINARY SHIP
}

\author{
Prof Leon de Kock
}

November 2012 
The Confessio of an academic Ahab:

Or, how I sank my own disciplinary ship

Inaugural lecture delivered on 19 November 2012

Prof Leon de Kock

Stellenbosch University

Editor: SU Language Centre

Printing: SUN MeDIA

ISBN: 978-0-7972-1400-2

Copyright $($ Stellenbosch University Language Centre 


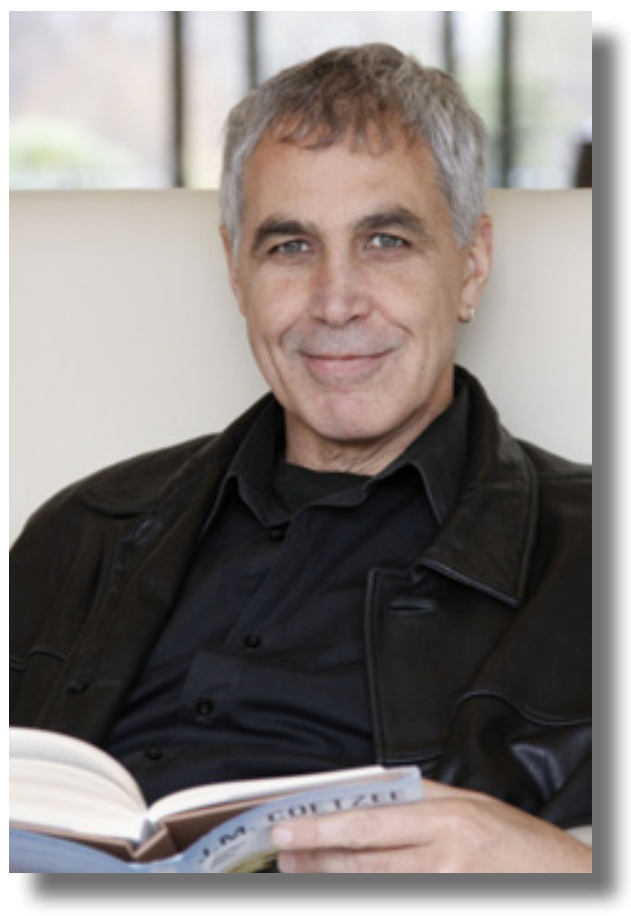

\section{ABOUT THE AUTHOR}

L eon de Kock matriculated at Mayfair High School, Johannesburg, in 1973. In 1974 he enrolled at the former Rand Afrikaans University, now the University of Johannesburg, to read for a BA in law, completing a BA Honours in English in 1978. After six years full time in journalism, he re-joined academia when a British Council scholarship enabled him to read Commonwealth, American and African Literature at the University of Leeds. Upon his return to South Africa from Leeds in 1984, he was appointed as lecturer in the department of English at the University of South Africa (UNISA), where he eventually became a full professor. In 2007/2008, he was appointed - after 22 years of service at UNISA - as Head of the School of Literature and Language Studies at the University of the Witwatersrand, assuming the position of personal professor. At Wits he also convened and expanded the creative writing programme. In 2010 he accepted a chair in English at Stellenbosch University. He has published widely, producing 37 accredited scholarly articles to date, with more in the pipeline, as well as 10 accredited book chapters, a monograph, several book-length works of literary translation, a novel, and three volumes of poetry. He has also edited literary works. His awards include the Pringle Prize (for poetry, 1995, and for best scholarly article, 20 I I), the SA Translators' Institute for Outstanding Translation (for Triomf, 2000), the SA Literary Awards (SALA) prize for literary translation, the Chancellor's Prize for Research, UNISA (twice), and the Council of Editors of Learned Journals' (CELJ, affiliated to the MLA) award for Best Special Issue of a journal, for Poetics Today 22 (2) 200I, South Africa in the Global Imaginary. 


\section{The Confessio of an academic Ahab: Or, how I sank my own disciplinary ship}

Imust confess, superficially and straight up, that I could not enter into the writing of this inaugural lecture - my second, and please, let it be my last - without first looking into the history of the "inaugural lecture" as a form. So I did some fairly quick digital browsing, the advantage of which is that the internet's synchronic purview of everything and anything available right this instant implicitly invokes, also, the inbuilt diachrony of time-bound expressions about form and value.

When, on 2 March 1954, the esteemed George Temple delivered his inaugural lecture as Sedleian Professor of Natural Philosophy before the University of Oxford, his introductory remarks included the following:

The only guiding principles are that the inaugural lecture, like the farewell speech, is delivered once for all; and, like the farewell, should have a theme not entirely irrelevant to the special interests and concerns of the lecturer, or of his hearers. With this wide freedom the inaugurator may well look to history to provide him with some models to imitate. History, indeed, does furnish specimens of at least three types of inaugural lecture - the sublime, the prophetic, and the familiar (Temple 1954: par. I).

As an example of the inaugural lecture that deals with the sublime, Temple cites St Thomas Aquinas delivering his Principium at the University of Paris in 1256. Here, says Temple (1954: par. 2), the "Angelic Doctor" meditates on "the sublimity of his subject; on the dignity required of its teachers; on the humility, sense, and responsiveness needed by its hearers". Reading this, I was struck by a gnawing sense that, in what we today call "English Studies" in South Africa, it is almost impossible to talk about the "sublimity" of the subject of literature without attracting unvoiced sneers and impatient foot-tapping; that it would be most inadvisable to advocate "dignity" on the part of its teachers, many of whom, across the world, are now iconoclastic cultural studies flaneurs who find the idea of "dignity" in relation to "literature studies" mildly ridiculous - bourgeois, in fact - treating literature instead in much the way they treated the kitchen fridge as teenagers, grabbing stuff fast, messily and not bothering much to clean up after they're done consuming this energy load for their other, more exciting pursuits; and that "modesty", in the discipline into which I am here, tonight, being inaugurated as a professor, is probably the last quality that English lecturers today would seek to inculcate in a student, encouraging them instead to assert their identitarian stamp, mix up genres like memoir and monograph and, like good post-postmodernists, post-postcolonialists and post-theory ventriloquists of the post-human dimensions of subjectivity, foreground their own radically situated, utterly contingent take on dubious epistemologies and questionable knowledge claims in the interest of breaking down disciplinary barriers altogether.

You will gather that I baulk at the current condition of the academy of "English" in Africa - particularly in South Africa, where we often belatedly take metropolitan trends far too far. I find many - though by no means all members of the discipline of "English" in this country both overconfident and complacent (a lethal cocktail for the making of knowledge, if ever there was one), disrespectful of the basic institution of literature itself - on which their entire discipline is indubitably based, and which they have to thank for their salaries in hard economic times - and airily dismissive of the elementary demands of methodological rigour (not to mention continuity) underlying most scholarly disciplines. Indeed, "English" has become a place where you can now do a PhD speculating on anything from the cultural uses of public space in Pretoria to the popular imaginary embedded in Nairobi's gospel mania, using as your source materials photographs, street pamphlets, popular songs and local newspaper reports. I could go on in this vein, but I won't, because I find myself thoroughly complicit in this state of affairs, and so, connecting the very new and the very old, I wish to frame this talk in the form of a confessional autobiographical narrative, a confessio, an intellectual memoir of sorts, so as to arrive at the point where I declare some form of principium, as Thomas Aquinas did, based on a quality I would call "achieved knowledge" that elusive amalgam of deep experience and a long life of continuous learning. My bottom line, and I shall state it now already, in advance of my argument, is the ever more urgent need for a principium in "English Studies" if the discipline is not to become, eventually, a complete laughing stock. I must confess that I have advised both my children not to read for English as part of their UCT undergraduate constellation of subjects. I said to them, frankly: "English has become a bit of a wank. Rather do philosophy ... rather learn some real intellectual rigour. Or learn a language - at least that's useful." I must confess also that I am not the only English literary academic who has said this to his children, his own flesh and blood, while continuing to teach unsuspecting students the subject we now delicately call "English Studies". 
So, this is the story of my complicity, because I have to confess, less superficially now, that, at the age of 29 or so, when I returned to academia from professional journalism via an MA at Leeds University, I began to feel even more galled about the state of the discipline than I had when I left it as an Honours graduate several years earlier. Now, armed with a few adult years of 20-something maturity, I wanted to conduct guerrilla warfare against the discipline's high-minded, pompous professors and their dubious certitudes. These jacket-and-tie Profs, these Philip Segals and Tony Woodwards, Ridley Beetons and Leon Hugos, some of them still in tweed, bestrode the early 1970s lecture theatres like veritable F.R. Leavises. They passionately propounded the universality of high-minded literature, and the deep irrelevance of what they snidely called the "local". They did not live in the "local". They lived in a "universal", "transcendental" realm in which imaginative genius of only the most exalted kind was the acknowledged legislator of the world, to abuse Sir Philip Sidney's maxim about poets. These neo-colonial dons happened to reside in South Africa, but really, in their own minds, they still lived in Oxbridge, and they regarded the Great Tradition as infinitely superior to the various forms of literary muck they occasionally spotted in the local murk. Many of them continued to act and live their intellectual lives in this way, even as the country went into states of emergency and the apartheid state did its best to censor the shape of public knowledge according to a nefarious and obsessive design. These professors, as the local marxisant critics would argue from the late 1970s onwards, were hegemonically complicit with a bourgeois ruling class in a broader system of racial capitalism. No doubt about it. How else does one explain their teaching of putatively "universal" or "transcendental" truths in literature derived from a Eurocentric bourgeois canon, while refusing to countenance the literary politics of local expression as the country literally burned before their widely shut eyes?

The local dons, however, saw the matter quite differently: they existed wholly within a universal order of beauty and truth, an order that transmogrified entirely the narrow interests of any politics, which they professed to despise. Both the nasty Afrikaner politicians, as much as the restive black population, needed the salve - the salvation? - of English Literature's transcendent verities about the supposed "human condition". This was the real answer - this was how subjects as abject as the Boers and the Blacks might be lifted from their lowly states. And they, the English Literature dons, were aesthetic transcendentalism's secular priests, second to none.

Imposing figures of this kind were my superiors when I re-entered academia as a temporary junior lecturer at UNISA in 1985. I quickly developed an unhealthily feverish desire to conduct a resistance campaign against them, along with their politically repulsive, elitist and exclusionary regimes of knowledge. To find the deeper source of these dark, insurrectionary impulses, however, I must go further back, to the mid-1970s, when I found myself a 21 -year-old English Honours student at the old Rand Afrikaans University in Johannesburg, very close to the white suburban slum of Mayfair, where I had rather inelegantly grown up. This upbringing is partially recorded in my memoiristic fiction, Bad Sex (201 I). I had started out with the notion that I would pole-vault right over the exciting-but-vulgar conditions of my youth by qualifying in law. Then, however, while still studying law and taking English as an extra major, I encountered one very special English tutor, and my life changed utterly. Often, that's all it takes - just one lecturer, among the bunch of them, who sets your imagination on fire with an enormous sense of possibility (and, I might add, agency) and there, in that extended moment, your universe shifts on its axis in ways you would never have been able to predict. This young, fresh-from-Cambridge scholar went by the full description of Mr Stephen Gray, senior lecturer in English. I soon discovered that he was a poet and, exhilaratingly, a new-on-the-scene, cutting-edge maker of books built on a determination to establish South African literature as a legitimate academic topic.

It is important to recall again, more fully, that in the 1970s - especially the first half, prior to the deep shock of the 1976 Soweto uprising - the professorial incumbents of English in places like Pretoria and Cape Town were wont to sneer aloud at the suggestion that one should make space for "local" writing (they refused to call it "literature") in their already over-stuffed curricula. These curricula were literally crammed with inestimable gems all the way from Beowulf to the Moderns, where, at roughly the 1930s, with T.S. Eliot, D.H. Lawrence, James Joyce and perhaps Virginia Woolf, they all said, "enough!" They were already at their wits' end because they'd been forced to leave out invaluable specimens like Spencer's "The Faerie Queen", and Dr Johnson, and memorable works by Dickens and Thackeray and Scott, simply because there wasn't enough space in the syllabi after the final inclusions had been made. The suggestion that dons of this ilk should actually sacrifice any of the "great" authors in the canons of English Literature for the sake of a Bosman ("Bós-mán? You've got to be kidding") or a Pringle (a minor Scottish poet?) above a Dylan Thomas (who'd also been squeezed out) or an Ezra Pound (who'd suffered a similar fate), was so self-evidently absurd that it hardly merited serious discussion. A nice throaty guffaw or two, along with some gleeful elbowing and head-shaking, would do quite nicely in response to that suggestion, thank you very much. 
So, in the midst of such a class of lecturers, I encountered Mr Gray. I soon realised that he was special, very special, in fact. He embodied both a cause - the relevance and vitality of indigenous (or "local" writing) and he was engaged in a civil but full-scale academic and writer's rebellion against an academy which refused to acknowledge that a figure such as he - an unrecognised "minor" author living in Johannesburg - had any claim to critical attention at all unless he first worked through the London publishing circuit, and then waited a few hundred years. Mr Gray, who was then working on the PhD that would become his landmark 1979 monograph, Southern African Literature: An Introduction (1979), was not only taking up arms against the buffoonish literary elitism of the "local-is-ghastly" crowd, he was also a real poet, novelist, critic and book-maker who was engaged, on a daily basis, with other, politically oppositional, "local" writers and visual artists across the then apartheidscorched country. Gray had already, by the mid- to late1970s, participated in co-creative projects with artists like Nils Burwitz ("The Beast's History" (1973), a visual/ poetic re-rendering of the Adamastor story) and the late Cecil Skotnes (The Assassination of Shaka, 1974). There were also collaborations with Walter Battiss.' Still later, via Gray, I met scores of writers and artists: Sipho Sepamla, Robert Kirby, Janet Suzman, Christo Coetzee, Richard Rive, Elsa Joubert, Mike Cope, Jan Rabie, Pieter-Dirk Uys, Etienne Leroux, Barrie Hough, Chris van Wyk, Mark Swift, Phil du Plessis, Welma Odendaal, Patrick Cullinan, Douglas Livingstone, Johan van Wyk, Rosa Keet, and many more. I mention these names at length not to namedrop, but because I continue to believe it is important to bring the names of writers and artists back into living memory and rescue neglected work from the amnesia that afflicts our discipline. At the time to which I am here referring, I also encountered the dead writers whose work Gray was furiously resuscitating, such as the (then) almost-forgotten Sol T. Plaatje, the entirely forgotten local novelist Douglas Blackburn, and similarly neglected local playwright Stephen Black. There was a fabulously ambitious publishing venture, Quagga Press, which Gray launched in collaboration with Skotnes; they debuted with a sumptuous hardback republication (carrying suggestive woodcuts by Skotnes) of Sol Plaatje's Mhudi ([1930] 1975), generously introduced by Tim Couzens, and meticulously edited in an act of curatorial love by Gray. There was more, lots more. I joined the board of literary magazine Donga, run by Welma Odendaal from the house next door to Gray's "semi" in Ninth Avenue, Mayfair, as one of its associate editors. Apart from me, the other co-editors were novelist Peter Wilhelm, poet and academic Peter Strauss, critic and poet Kelwyn Sole, and writer-academic Mbulelo Mzamane. The openly defiant Donga was banned by the State after eight issues. ${ }^{2}$ At about the same time, I was (loosely) drawn into a project with Gray and Ampie Coetzee, the dangerously "radical" Afrikaans literature scholar at Wits University and close friend of Breyten Breytenbach, to contribute to a collection of translated Breytenbach poems, which appeared as the book And Death as White as Words (1978), bringing to light what I then realised was the astonishingly powerful poetry of this man Breytenbach, who in only a few years would be jailed for political treason against the apartheid state. During his incarceration he would write possibly his most elusively allusive book, Mouroir. Bespieëlende notas van 'n roman (1983), which appeared in Breytenbach's own hand in English as Mouroir. Mirror-notes of a Novel (1984). The five poems I co-translated for And Death as White as Words (two with Stephen Gray and three with Sonja van Schalkwyk), ${ }^{3}$ were my first-ever contribution to a book, and my unwitting introduction to an activity to which I would later return with much more serious purpose. ${ }^{4}$ I was in my early twenties, and I was hooked, big time, as they say. When you walked into Gray's little Mayfair "semi" - across the road from where I quite accidentally landed up myself, in my own little "semi", my first ever adult venture into living in my own space - you could smell the creative smoke coming off Gray's home industry, along with the beguiling scent of Gauloises plain, which he chainsmoked for many years. Quite simply, I had inadvertently bumped into one of the most exciting living writers of my own time in South Africa, and certainly one of the few academics who was rooted both in academia - in revised scholarly explorations of indigeneity - and in the enormously sexy world of creative production.

However, it soon became clear to me that there was little or no space in academia, and in "English", for such urgent preoccupations, except perhaps on the opposite banks of the discipline's outermost boundaries - on the other side of the Vaal River, maybe, where Etienne Leroux was laughing up his sleeve as he wrote Magersfontein, O Magersfontein! (1976) on his family farm, "Wagenmakersdrift", about $10 \mathrm{~km}$ outside Koffiefontein. I know because I accompanied Gray on a visit there. So, at the end of my Honours degree, in 1978, I left academia to become what I thought of as a real writer in a real world, rather than languish, along with most academics in the discipline of English, in a state of wilful ignorance about what was going on in the country at large, seeing no evil, hearing no evil, and speaking no evil. I took the first job I could get - as a reporter for the Johannesburg daily Beeld, from whose offices in Doornfontein, Johannesburg, I was immediately dispatched to the Magistrate's Courts in Marshall Street. There, I witnessed the goings on of the real volk, the kind of folk I knew from my childhood, with their daily dramas of desperate measures and legal consequences. I worked as a full-time journalist for five years, moving from court reporter to crime reporter to arts writer 
before I eventually succumbed to the quiet, elegant word-art of sub-editing. When I left full-time journalism in late 1983 to take up the British Council scholarship at Leeds University, I had progressed to the position of Chief Sub-Editor (Finance) at The Star in Johannesburg. But I felt that my career in journalism was lacking in intellectual heft.

The British Council scholarship was a timely rescue for me. Full-time journalism, especially as a senior editor, head down and turned away from the world of writing and literature, was wearing me down. So off I went to Leeds to study "Commonwealth", American and African literature under the likes of Leeds luminaries Arthur Ravenscroft and Shirley Chew. ("Commonwealth Literature" had been virtually founded at Leeds University by the unstoppable William Walsh, author of books on Indian literature, V.S. Naipaul, Patrick White, and multiple similar volumes. Wole Soyinka also made an important turn at Leeds.) It was with a reinvigorated, more educated sense of worldliness that I found myself re-entering the discipline of university English at the University of South Africa (UNISA). I had graduated cum laude at Leeds with a spanking new MA, of which I was inordinately proud. At UNISA I started out as a "temporary junior lecturer", and I stayed for much, much too long, 22 years, in fact, progressing all the way from my "temporary" and junior state to that of a full professor, for which I paid my dues in an inaugural lecture in the UNISA Senate Hall in 2003..$^{5}$ This was a career that also contained a marriage of II years and the birth of a family. It saw the publication of my monograph, Civilising Barbarians (2006), my first volume of poetry, Bloodsong (2007), my translation of Marlene van Niekerk's paradigm-smashing novel Triomf (2009), and a few other books besides. Most importantly, though, this period, 1985 to 2007, saw a disciplinary revolution in which "English Literature" morphed into "English Studies". In my own small way, located as I was in the North, I helped to further this revolution, in whose wake I now find myself if not drowning, then at least waving.

The story of this rebellion might, I hope, serve to bring into focus the intellectual and theoretical sources of my desire, in the 1970s and 1980s, to overthrow the neocolonial academic fortress of "English". I was consumed with a fiery sense of unjust imposition against indigenous literature, which Gray was fast proving did in fact exist with each new book he compiled or edited: Writer's Territory (1973), A World of their Own (1976), On the Edge of the World (1974) and its revised, expanded successor, Modem South African Stories (1980, 2002), in whose 1980 edition my own story, "Something Great", which had first appeared in Donga, had been taken up, only to be left out again in later editions. So, Gray and others like him - mainly writers such as Sheila Roberts, J.M. Coetzee and Jack Cope, editor of Cape-based Contrast literary journal, among others - were fast disproving the localyokel myth. My desire to rebel was further fuelled by the theory I was reading, mostly in the area we eventually came to call "poststructuralism", although in France, where it originated, it was often referred to as "late structuralism". And it was this conjunction of a concern with indigeneity, along with theoretical models allowing for a decentring of authoritative (in the South African case, neo-colonial) regimes of meaning, which turned me into a self-proclaimed "postcolonial" scholar. When Bill Ashcroft, Gareth Griffiths and Helen Tiffin published their academic bestseller The Empire Strikes Back in 1989, such a conjunction became both self-evident and highly attractive to scholars across the old Commonwealth, people who wanted to shake off the "cultural cringe", and along with it, at last, the British Empire, growing instead into their own sense of literary-cultural becoming. This conjunction found expression in Civilising Barbarians, which started out as a $\mathrm{PhD}$ project under the UNISA English department's most assured theoretician, Ivan Rabinowitz, with astute historian Greg Cuthbertson cosupervising. Civilising Barbarians read discursive patterns from missionary records, evangelical treatises, newspaper clippings, and accounts of fabulous travels by Moffat and Livingstone in the service of God. The enormity of the intellectual "Damascus moment" implicated in putting poststructuralist decentering to the service of indigenous agency should not be underestimated. It made us see our own literature afresh, in many cases for the first time. Such an event, or process, can be likened to the idea of Afrikaans literature academics suddenly realising, in the 1970s, that they'd mistakenly been reading only Netherlandic works; now they were discovering that authors such as Totius, Eugène N. Marais, C. Louis Leipoldt, C.J. Langenhoven, C.M. van den Heever, M.E.R., Etienne Leroux, André Brink, N.P. van Wyk Louw, Adam Small, Breyten Breytenbach, and scores more, were in fact talking to them, about them, and with them. Imagine that! Imagine refusing to talk back. These were their own writers, writers who were busy cocreating the literary heterocosm in which such academics themselves existed. To ignore them would require an astonishing form of willed cultural blindness. To refuse to recognise one's own kind, from the viewpoint of Afrikaans academics, today still, seems an appropriately laughable idea. And yet that is exactly what the "English"-speaking academics in South Africa, many of them South Africans by birth, if not by inclination, were doing, and had been doing for decades. In many cases, English Studies academics are now doing this all over again, along with large parts of the English-speaking media in South Africa, replacing the notion of the "real" centre of metropolitan English - 
London and New York in the old days - with the new discourses of globalism and "world literature" in English. ${ }^{6}$ In the late 1970s, such willed ignorance among English academics remained prevalent, despite periodic wrangling about what to do with "local writing" at several national conferences over the years. Without fail, these debates reached a stalemate on the matter of the "inferiority" of SAE writing to metropolitan English literature, ${ }^{7}$ not to mention the thorny issue of which classics to drop for the sake of a Bosman, a Plomer, a Campbell, Pringle, Smith or Schreiner. That's not to mention Plaatje, Mphahlele, Paton, Butler, Modisane and Serote. So, Herman Charles Bosman, a folk writer the equal of Australia's revered Henry Lawson, and Nadine Gordimer, like Australia's Patrick White a writer who would one day win the Nobel Prize for Literature, had to stay outside the doors of academe.

There was nothing for it but to fight the matter out. And, in UNISA's English department, I led a minor charge, with fiery idealism and hot-headed passion. I must have come across as disturbingly feverish to my then professorial superiors, who were good, decent, well brought-up people with names like Leon Hugo, Ted Harty, Ernest Pereira, lan Ferguson and Shirley Kossick. At the same time, at the same institution, my colleague Marlene van Niekerk was conducting a similar rebellion against the neglect, in the Department of Philosophy where she was teaching, of African philosophy, for which the philosophy dons had substituted the wholly reductive and false notion of "animism" - as if that's all Africa was about, philosophically speaking. Well, the young Marlene van Niekerk had quite a bit to say in response to that dubious notion, have no doubt.

As suggested above, the theoretical conjunction in my own scholarly rebellion against the look and feel of English studies was a copula joining poststructuralist theory with postcolonial imperatives. My belated awakening to poststructuralism came via Robert Young's 1981 book, Untying the Text: A Poststructuralist Reader, in which, sitting in my UNISA cubby-hole, I belatedly discovered Michel Foucault's pivotal text, "The Order of Discourse". The reading of this piece was to become what some people call a "turnkey" moment for my entire academic career. Imagine my excitement when I realised that Foucault, in a sense, was authorising an intellectually and theoretically legitimate counter-discourse to authoritative institutional discourse itself, in ringing, Nietszchean phrases like "will to truth" which, in Foucault's famous inaugural lecture, is "renewed by ... institutional support", and further, that "this will to truth", "leaning ... on a support and an institutional distribution - tends to exert a sort of pressure and something like a power of constraint ... on other discourses" (Foucault in Young 1981: 55). I read and I read and I read. My goodness, I had discovered Foucault, the archaeology of knowledge, the discipline of punishment, the birth of the clinic, the history of sexuality, and of madness. My senior colleagues - the professors under whom I now had to work - surely knew nothing about this stuff! I knew, because l'd heard them say it out aloud: they didn't like what was then dismissively compacted together under the sneer-word, "theory". They were died-in-the-wool Prac Crit people - this was their tried and trusted methodology. It worked, and if it ain't broke, don't fix it! Their entire institutional pedagogy was based on the inculcation of skills of literary analysis upon a consecrated body of mainstream English literary texts. Over and out. Figures like Foucault, and now also Derrida, along with that upstart conjunction Deleuze and Guattari, and with names like De Man, Spivak, and later Bhabha bringing up the rear, were way, way out of sight, on the far borders of our institutional location, our critical habitus, if you will. But who could possibly stop the tide of the new-fangled Frenchies, with Roland Barthes and Pierre Bourdieu and Jean Baudrillard and any number of other distinctly un-English thinkers now making the rote discipline of "English" look distinctly stale, dead on its feet, and very, very tired. In the contest between 'Prac Crit' (based on both the work of I.A. Richards and the midcentury blossoming of the New Criticism in the US) and the emerging glories of modern Semiotics and Cultural Studies, it was a no-brainer.

These were heady times. It was now the mid- to late1980s; there were States of Emergency, a growing sense that politics was all-pervasive, and that institutions could no longer stand aside. Knowledge and its production were not, many of us came to believe, immune to what the emergent Marxist critics, conveniently converging around Wits University in Johannesburg, were calling "hegemony" and "ideological interpellation", drawing on Marx, Gramsci, Althusser et al. Wits was a churning intellectual locale, giving birth to bold cross-disciplinary forays such as the History Workshop, with its "History from Below" ethos, ${ }^{8}$ and producing names like Charles van Onselen, Belinda Bozzoli, Tim Couzens, Stephen Clingman, Isabel Hofmeyr, Deborah Posel and still others. In civil society, intellectual ferment, especially in the NGO, media and alternative publishing fields, was running high. A young Gerrit Olivier (later to become Dean of Humanities at Wits for two terms) set up Taurus, a publishing house that gave voice to Afrikaans resistance writers such as Koos Prinsloo, Eben Venter, Lettie Viljoen (i.e. Ingrid Winterbach), R.R. Ryger, and many others, while Ravan Press in Braamfontein, Johannesburg, close by to Wits, had already seen J.M. Coetzee's Dusklands (1974), In The Heart of the Country (1977), Waiting for the Barbarians (1980), Life \& Times of Michael K (1983), and Foe (1986) 
into the world. Eventually, by dint of persistent committee debating, I managed to get Waiting for the Barbarians onto the UNISA undergraduate curriculum. Later, I managed to convince my professorial elders that Nadine Gordimer's Booker Prize-winning The Conservationist (1974) had to be there, too, following a ding-dong shouting match with the late Shirley Kossick in a UNISA staff meeting. It may sound unbelievable now, but these were major victories in the mid-1980s, the era of alpha-male P.W. Botha, the androgynous Boy George and trans-ethnic phenomenon Johnny Clegg. As a footnote to this, the following: on a UNISA "group visit" to Cape Town to give lectures in the early 1990s, one of the people in my Waiting for the Barbarians class was a young UNISA undergraduate called Meg Samuelson. I know this because the person who is now Professor Meg Samuelson of UCT told me so soon after I arrived at Stellenbosch in 2010 . She had found the lecture and the topic inspiring, and she attributed her desire to continue in the discipline of English partly, at least, to this moment in her life.

I see that my narrative is beginning to outrun my available time, so at this point I must abandon the comfort of relatively chronological storytelling for a cross-cutting, theoretically inflected account of what has transpired in "English/English Studies" since the early 1990s. More briefly, then: what I would call the (somewhat belated) "postcolonial moment" in South Africa, beginning in the late 1980s - and fully anticipated by Coetzee's Foe in 1986 - was firmly buttressed by the poststructuralist emphasis on decentering regimes of knowledge. The postcolonial "school" in South Africa, now publicly identified with David Attwell's and my own work in the 1990s, was also fired by the deconstructionist imperative to demonstrate that meaning, and therefore authoritative invocations of the real, were never entirely "present" in language. "There is nothing outside the text," Derrida infamously said. South African Marxist critics, who were on quite a roll in the late 1980s, detested such relativisation of the so-called "real" and sniped mercilessly at "postcolonial" critics. They saw us as elitist idealists or liberal pluralists (siesa!) in disguise. To them, we were sheep in wolf's clothing, as one of these acidulous figures actually pronounced publicly, so virulent was their antipathy. But the postcolonial theory movement gained ever greater purchase, even as the certitudes of Marxist literary criticism began to falter visibly in global English studies. Partly, the po-co movement, solidly based on the authority-robbing discourses of poststructuralism and, in some cases, on psychoanalytic critique derived from Freud and Lacan, also found comradely heft in the now-flourishing Cultural Studies movement associated with the Birmingham School and the towering figure of Stuart Hall. The postcolonial people and the Cultural Studies folk shared a sense of the importance of, among others factors, materialism and class, contra the claims of the Marxists. In addition, they both relied squarely on an expanded, perhaps even an exploded, notion of the term "text". This suddenly vast notion of "the text" naturally drew on modern semiotics, with divinely readable figures such as Barthes and Umberto Eco showing the way. The methods of semiology, Barthes showed, could take on anything as an analysable "text". Neither wrestling matches nor soap powders were immune to semiotic readings. This point in my narrative on its own could make up an entire book-length study, or a lengthy journal article, at least, but I can see your concentration beginning to wane now, so I must hurry.

On, then, to the next conjuncture in my story, namely the collapse of the Westphalian nation state in the wake of the Berlin Wall's hacking down in 1989 and, along with it, the actual disintegration of the Cold War and Communism as a mode of government. The nation state continued to operate everywhere, of course, but the rising new order of globalisation, on the wings of a growing digital revolution, was busy bringing about a worldwide information network (the World Wide Web, or "www") in which the flow of data, money and ideas could no longer be regulated entirely within the legal and superstructural domain of the nation state. Oppressive nation states, many of them former Western colonies that had gone the way of Fanon's predictions, and ex-Soviet satellite states, not to mention tinpot dictatorships in the East, were increasingly squeezing out dissidents and producing boatsful of refugees. These stateless people were flooding metropoles far away from their countries of birth, in wider distribution than earlier human pogroms, and they helped to create what Nancy Fraser, in "Transnationalising the Public Sphere", called a "postnational constellation" (2007: 14) - a place in which Fraser detected a "transnational community of risk" (19). For Fraser, in such newly constellated transnational communities, the locus of legitimacy - of ideas, ideologies and systems - had shifted from the nation state to the postnational, global "public sphere". This was an entirely new space of intersubjectivity and legitimation in a postWestphalian world community - and it was enabled by the digital revolution, offering the dispersed subjects of the migrant-heavy world order alternative room for selfrecognition, or new (though deferred) senses of home, so to speak.

One of the casualties of the transnational shift was, in Fraser's argument, the stability and viability of the category of the "national" as a portmanteau for literature. In Fraser's critique of Habermas's public sphere, she questions his tacit assumption that a public sphere rests on a "national vernacular literature, which supplies the shared social imaginary needed to underpin solidarity" 
(18). This assumption, Fraser suggests, is "counterfactual" in view of the "increased salience of cultural hybridity and hybridization, including the rise of "world literature"' (1819). Fraser cites, too, the rise of global mass entertainment, and what she calls the "spectacular rise of visual culture, or better, of the enhanced salience of the visual within culture, and the relative decline of print and the literary" (19). In all these instances, as Fraser suggests, it is difficult to recognise the sort of national literary cultural formation seen by Habermas and by Benedict Anderson as critical to the subjective stance of public sphere interlocutors (19).

Fraser began saying these things in the early 1990s. I need not belabour the point that, in fact, her prognostications about the rise of transnational public spheres, and the decline of national imaginaries as the primary realm of literary-cultural pursuits, have proven to be on the money. I would argue, though, that her theories are vulnerable to critique with regard to the continued exuberance of the "local", regardless of the drooping stalk of the "national". Nonetheless, to tie my own confessional narrative up quite nicely at this late point in my address, the rebellion in which I began to participate in the 1980s, for the sake of recognising a South African national literature, eventually reached a point, in the wake of po-co and po-mo, with their expansion of the idea of text and their explosion of originating certainties, where all national literatures, and all ideas of a bounded "text", were also blown to smithereens. Embedded within the theoreticalconceptual struggle against the elitist hegemony of a metropolitan and high-minded literature, in other words, were the seeds of a critical revolution that would also destroy the safety net of a nationally bounded, indigenous literature as the primary literary-cultural imaginary of South African subjects. As I put it in my keynote address to the delegates of the Association of University English Teachers of South Africa in 201 I, in the Settler country hamlet called Grahamstown:

First we threw out the dead white males. Then we ditched "metropolitan" notions of literary universalism. We discarded genre theory as old hat. The New Criticism went flying out the window. We decided that form and function studies were limiting. We decried belletristic elitism. We stormed the castle of literary verities, invoking the French and their wonderful theoretical marshlands, or are those rhizomes? We began to find even the idea of a text as a stable entity limiting. Language was, after all, a disappearing trace. Did we think such embedded and congratulatory self-annihilation would stop with us? It has become the spirit of our nondiscipline. First we take Manhattan, then we take Berlin, as Leonard Cohen said. Singing as we march. (De Kock 20। I: 7-8)
So, this is my confessio. I have collaborated in the downfall not only of the national literature to whose study I remain committed - South African literature - but also in the very stability and continued existence of the literary text as my discipline's central object of study. If my public position-taking over the past two years, railing against South African academics' neglect of their own writers, has seemed anachronistic and contradictory, that's because my protestations have indeed been contradictory, perhaps even anachronistic, which is a harsh word to use about oneself, even by a known self-flagellator. And yet my discomfort about the state of our (non)discipline is no less for this confession. I now believe that delimiting the field of "English" to literature, mainly, would paradoxically open up the possibility of a more informed and normative evaluation of literature, whereas the "social text" approach - I have come to realise - often leads to a diluted, mostly descriptive method in which critics, flailing about methodologically in the no-man's-land of nondisciplinarity, are afraid to make judgements. How, after all, does one judge almost anything and almost everything? We need more normative evaluation of literature, of writing, based on the expertise which only our discipline, along with other disciplines in literature, can confidently consolidate and expand. Which new works of writing are better and which worse, and why? On what grounds? What's going on in South African and African writing, viewed as a multilingual, comprehensive undertaking? In those two questions alone is enough work for another three decades of intensive research and scholarship. Such position-taking should be more than the flip, throwaway assertions, with luminous-sounding hints of deeper "social" implications, to which we have latterly become accustomed, a kind of lipservice to literature.

We pretend to uphold a plurality of approaches, making space for everything from old-fashioned textual editing and criticism, to "Public Culture" and critical theory, in which literary texts need not feature at all. Surely, you might argue, such a plurality of approach is healthy? Surely we should give our postgraduate students this wide ambit of choice in choosing their PhD topics? And yet we also know that this choice is practically constrained by the availability of supervisors in any one department of English at any one time. Postgraduates have a good sense of the community of academics and what their interests are; they quickly see which topics are currently "hot", which methods most admired, and they will often want to fall in with the perceived academic avant-garde because this is where they're likely to find the most favour in terms of publication, funding and popular supervisors, not to mention postdocs and the distant possibility of an academic post. So, one may ask, how much choice do our students really have? Departments of English are 
turning away legitimate topics for postgraduate study owing to a lack of both interest and expertise. This fact blows out of the water the idea that we operate with open agendas. The truth is that our postgraduate agendas are contested and relatively limited. When a critical mass of academics begins to disavow the imaginative literary or performative artefact as a primary object of study, we are not merely "expanding" the discipline, as is often claimed, not merely heeding the clarion call to interdisciplinarity, or transdisciplinarity; we are contesting the available space in the discipline, advancing one disciplinary focus - even if we wickedly call it transdisciplinarity - above others. In doing this, we narrow the scope for innovation and expansion in a specifically literary criticism, and we avoid the disciplinary duty of better serving our primary object of study.

I am in imminent danger of losing your concentration entirely, and I must now sum up. In conclusion, then, the following two questions, which I must state and leave open: As much as we all acknowledge the impossibility, and the undesirability, of giving up on the transdisciplinary gains of "English Studies" over the past thirty years or so, how will we prevent the literary text - the only object of our discipline whose close study cannot be appropriated by other disciplines - from becoming a quaint old relic? And how, then, especially in the years to come, will we hold our disciplinary ground, our raison d'être, both institutionally in terms of survival, and philosophically, as a distinct field, against almost anyone and almost anything? My short answer is a re-evaluation, not of "national" literature, but of the valence of the local, indeed the hyper-local, as JeanneMarie Jackson (20II) puts it - and yes, including Die Antwoord - without which globalism and transnationalism have no dialectic counterpoint, no guts, at all. ${ }^{9}$

\section{NOTES}

I) In a brochure accompanying the exhibition "Printing the Seventies: Battiss, Burwitz, Skotnes and More" at Gallery AOP (Johannesburg, June 20 I2), Gray explains how, when he returned from Cambridge and the UK in the late 1960s, he fell in with people like the Afrikaans poet Phil du Plessis, who had been editing the literary journal Wurm. Together with Wilma Stockenström, Gray and Du Plessis edited IZWI, which ran from October I97| to December 1974. Each of twenty numbers, Gray notes, selling at 50c each, was to contain one graphic as an incentive to buyers. Gray writes: "Battiss himself out at Giotto's Hill in Menlo Park generously signed 250 copies of one of his erotic fantasy drawings for us.... Likewise did Christo Coetzee, Peter Clarke, Helmut Starcke, Raymond Andrews, Berenice Michelow, Wopko Jensma and more. Covers were donated by the likes of Alice Goldin, Mike Costello, Alexis Preller and even Skotnes himself for No. 14. By No. 13 Burwitz had outdone them all by offering us a 7-colour silkscreen poster, including printed poems of mine called 'The Beast's History', in a limited collector's edition of 240."

2) Donga was set up in 1976 and banned in April 1978, after eight issues. Michael Gardner, in his unpublished paper, "Time to Talk: Literary Magazines in the PretoriaJohannesburg Region, 1956 to 1978", offers the following brief history: "Issue 4 challenged conventional approaches to the teaching of literature, saying 'to hell with Europe and Western culture', asserting that educational institutions should teach African literature for Africans. Nearly all of the 700 copies printed sold out. Seven months later this issue was banned, after two further issues of the magazine had appeared. The sixth issue (April 1977) announced the liaison between Donga and the black writers' group Medupe, then led by Duma Ndlovu and Mothobi Mutloatse, an organisation banned in 1977 along with black-run newspapers and many cultural groups. Then in April 1978, after eight issues, Donga was finally prohibited despite the care taken by the editors to preserve it as an outlet for 'writers who were experiencing the increasing difficulty of having controversial political work printed in any form'." (Gardner n.d.: 24).

3) The poems translated with Stephen Gray are "Tot siens, Kaapstad" / "Goodbye, Cape Town" (39-4I) and "Walvis in die Berg" / "Whale in the Mountain" (63). With Sonja van Schalkwyk, "Die Swart Stad" / "The Black City" (37); "Septembersee" / "September Sea" (43-47); and "In exile from exile" (the Afrikaans poem's title also rendered thus, in English, 49).

4) In 1999, my translation of Marlene van Niekerk's novel, Triomf, was published by Jonathan Ball in South Africa and by Little, Brown in the UK, in two variant editions, a "South African" translation including Afrikaans and SAE slang for Jonathan Ball, and an "international" version - with all Afrikanerisms translated or glossed - for Little, Brown. In 2004 the "international" translation was published by Overlook Press in New York. My translation of Triomf was named winner of the inaugural South African Translators' Institute (SATI) prize for outstanding translation in 2000. In 201 I, my translations of a cycle of poems by Cas Vos, Intieme Afwesige (2010), were awarded the South African Literary Awards (SALA) prize for literary translation. Also in 201 I, another volume of my translations of Cas Vos's poems, Duskant die Donker / Before it Darkens, was published by Protea Book House. At the time of 
writing, my translation of Etienne van Heerden's In Stede van die Liefde (2005) is in the final stages of editing for publication by Penguin Books (South Africa), to appear in English as In Love's Place, presumably in 2013. Also completed at the time of writing is a translation of Ingrid Winterbach's Die Benederyk (20I0), set for publication in 2013, provisionally entitled Going Under.

5) Published as " $S(p)$ lice of Life:The Dominance of the Real in South African Literary Culture" in the Journal of Literary Studies (2003b).

6) For a critique of "globalism" in this vein, and of "globalisation", see Hitchcock (2003) and Szeman (2007); Jackson (2011: 343) talks about the "hyperlocal in a world-systems age", and offers as a prelude to her argument about Triomf and its "hyper-local" dogs, which cannot be domesticated by any global allegory, the following statement: "From its consignment to the seemingly static world of a shunned house in a wornout suburb, Triomf throws a wrench in the too-dominant model of global flux" (344).

7) See Derek Barker (2007), where he discusses various national conferences of South African English literature academics in the previous century. Barker (|80-|8|) writes: "The conferences held by university departments of English in 1946, 1948 and 1951, where matters of perceived importance were up for discussion, were striking in terms of the sheer omission of debate on the topic of South African literature. One key theme upon which general consensus reigned was the need to abandon 'the traditional practice of teaching "periods of literature" in a broad historical manner' and apply instead the 'direct method' of 'thorough, honest and critical reading of a sufficient number of great representative works."' Barker writes that the "Conference of Writers, Publishers, Editors and University Teachers of English" in 1956 marked a turning point: "For the first time, on a tertiary-level forum (that is, one in which literary academics took part), South African literary production was openly debated. According to the Proceedings: Those who opposed the inclusion [of South African production in the English literature course] did so on the following grounds: that such a practice might lead to some loss in the value of a literature course (local writers might displace Shakespeare, Milton and others) $\ldots$ and that local writers might be rated above their worth" (187). There you have it. See also Barker and De Kock (2008).

8) For a fascinating treatise on the radical, marxisant "history from below" movement in South Africa, radiating outwards from the Wits History Workshop (from the late 1970s through to the 1980s and beyond), and from the now-defunct African Studies Institute (led by the revered, terrifying figure of Charles van Onselen, along with Tim Couzens), see Belinda Bozzoli's African Studies Institute paper, "Class Community and Ideology in the Evolution of South African Society" (1985).

9) This is, indeed, also the import of Jackson's recent $\mathrm{PhD}$ dissertation, Close to Home: Forms of Isolation in the Postcolonial Province (20I2).

\section{WORKS CITED}

Ashcroft, Bill, Griffiths, Gareth, and Tiffin, Helen. 1989. The Empire Strikes Back: Theory and Practice in Postcolonial Literatures. London: Routledge.

Barker, Derek. 2007. English Academic Literary Discourse in South Africa 1958-2004: A Review of I I Academic Journals. D. Litt et Phil. UNISA. Published electronically at http://ubt.opus. hbz-nrw.de/volltexte/2007/437/pdf/EALD SA 19582004 D Barker.pdf

Barker, Derek, and De Kock, Leon. 2008. "How South African Literature Got Squeezed Out, and Then Slipped In: English Academic Literary Discourse in South Africa 1946-1996." English Studies in Africa 50 (2; Jubilee Edition): 19-46.

Bozzoli, Belinda. 1985. "Class Community and Ideology in the Evolution of South African Society". Paper delivered at an African Studies Seminar event, African Studies Institute, University of the Witwatersrand, May, viewed 23 October 2012, from http://wiredspace.wits.ac.za/jspuil bitstream/10539/84|4/I/ISS-42.pdf

Breytenbach, Breyten. 1978. And Death White as Words: An Anthology of the Poetry of Breyten Breytenbach: A Bilingual Text with English Translations. London: Collings.

Coetzee, J.M. 1986. Foe. Johannesburg: Ravan Press.

1983. Life \& Times of Michael K. Johannesburg: Ravan Press.

1980. Waiting for the Barbarians. Johannesburg: Ravan Press.

1977. In the Heart of the Country. Johannesburg: Ravan Press.

1974. Dusklands. Johannesburg: Ravan Press.

De Kock, Leon. 2011. "What We Mean When We Talk about English:The Changing Currency and Value of Literary Studies in South Africa." Keynote Address, Association of University English Teachers of Southern Africa (AUETSA), 13 July. Unpublished paper.

2003a. "S(p)lice of Life: The Dominance of the 
Real in South African Literary Culture." Inaugural Address. Pretoria: University of South Africa, October.

. 2003b. S(p)lice of Life: Manipulations of the 'Real' in South African English Literary Culture. Journal of Literary Studies 19 (I): 82- 102.

1997. Bloodsong: Poems. Cape Town: Snailpress.

1996. Civilising Barbarians: Missionary Narrative and African Textual Response in Nineteenth-Century South Africa. Johannesburg: Witwatersrand University Press and Lovedale Press.

Fraser, Nancy. 2007."Transnationalizing the Public Sphere: On the Legitimacy and Efficacy of Public Opinion in a Post-Westphalian World". Theory, Culture \& Society 24 (4): 7-30, viewed 23 October, from http://eipcp.net/transversal/0605/fraser/en

Gardner, Michael. n.d. "Time to Talk: Literary Magazines in the Pretoria-Johannesburg Region, 1956 to 1978", $\quad$ http://www.art-archives-southafrica. ch, viewed 22 October, from http://www.artarchives-southafrica.ch/PDFs/Gardiner surveySA-poetry 1956-1978.pdf

Gordimer, Nadine. 1974. The Conservationist. London: Jonathan Cape

Gray, Stephen. 2012. "Printing the Seventies: Battiss, Burwitz, Skotnes and More. The Stephen Gray Collection", galleryaop.com, viewed 22 October 20 I2, from http://galleryaop.com/oid\%5Cdownl oads $\% 5 \mathrm{Cl} \% 5 \mathrm{C} 78 \quad$ | $3 \quad 52 \quad 17$ AM AOP\%20 Gray\%20brochure\%20web.pdf

Modern South African Short Stories. 2002 [Revised edition of 1980 AD Donker edition, itself a revised edition of On the Edge of the World, AD Donker 1974]. Johannesburg: Jonathan Ball.

.Writer's Territory. 1999 [1973; $2^{\text {nd }}$ edition 1979; 1994]. Cape Town: Maskew Miller Longman. . 1979. Southern African Literature: An Introduction. Cape Town: David Philip.

. 1976. A World of their Own: Southern African Poets of the Seventies. Johannesburg: AD Donker.

."The Beast's History". 1973. Exhibited at the Main Gallery, South African Association of the Arts, Carlton Hotel, Johannesburg, August-September. Limited-edition (270 copies) screen-print in colours with accompanying verse.

- with Cecil Skotnes. 1974. The Assassination of Shaka. (Full title: The Assassination of Shaka by Mhlangane Dingane and Mbopa on 22 September 1828 at Dukuza by which act the Zulu nation first lost its empire.) Johannesburg: McGraw-Hill.

Hitchcock, Peter. 2003. Imaginary States: Studies in Cultural Transnationalism. Chicago: University of Illinois
Press.

Jackson, Jeanne-Marie. 2012. Close to Home: Forms of Isolation in the Postcolonial Province. Unpublished $\mathrm{PhD}$ dissertation, Comparative Literature, Yale University.

2011. "Going to the Dogs: Enduring Isolation in Marlene van Niekerk's Triomf.' Studies in the Novel 43.3: 343-362.

Leroux, Etienne. 1976. Magersfontein, O Magersfontein! Cape Town: Human \& Rousseau.

Plaatjie, Sol T. Mhudi. [1930] 1975. Johannesburg: Quagga Press.

Szeman, Imre. 2007. "Poetics and the Politics of Globalization." Studies in Canadian Literature / Études en littérature canadienne (SLC / ÉLC), 32 (2): $|48-16|$.

Temple, George, 1954, "The Classic \& Romantic in Natural Philosophy", history.mcs.st-andrews. ac.uk, viewed 22 October 2012, from http:// www-history.mcs.st-andrews.ac.uk/Extras/ Temple_Inaugural_l.html

Van Heerden, Etienne. 2005. In Stede van die Liefde. Cape Town:Tafelberg.

Van Niekerk, Marlene. 1999. Triomf. Trans. Leon de Kock. London: Little Brown, (hardcover, followed by Abacus paperback, 1999); South African version: Johannesburg \& Cape Town: Jonathan Ball \& Queillerie, 1999. US edition: Overlook Press, 2004. Film based on translation by Michael Raeburn, 2009.

Vos, Cas. 20II. Duskant die Donker / Before it Darkens. Trans. Leon de Kock. Pretoria: Protea Book House.

2010. Intimately Absent. Trans. Leon de Kock. Pretoria: Protea Book House.

Winterbach, Ingrid. 20I0. Die Benederyk. Cape Town: Human \& Rousseau.

Young, Robert. 1981. Untying the Text: A Poststructuralist Reader. London: Routledge \& Kegan Paul. 
